\title{
Communication
}

\section{Propagation of Jasminum parkeri: A Critically Endangered Wild Ornamental Woody Shrub from Western Himalaya}

\author{
Ujala Kashyap ${ }^{1,2, *(\mathbb{D})}$, Anjali Chandel ${ }^{1}$, Diksha Sharma ${ }^{1}$, Sonali Bhardwaj ${ }^{1}$ and Bhavya Bhargava ${ }^{1,2, *(1)}$ \\ 1 Department of Agrotechnology, CSIR-Institute of Himalayan Bioresource Technology, Post Box No. 6, \\ Palampur 176061, H.P., India; anjalichandel368@gmail.com (A.C.); ds9816929176@gmail.com (D.S.); \\ bhardwajsonali21@gmail.com (S.B.) \\ 2 Academy of Scientific and Innovative Research, Ghaziabad, Uttar Pradesh 201002, India \\ * Correspondence: Ujalakashyap777@gmail.com (U.K.); bhavyabhargava01@gmail.com or \\ bhavya@ihbt.res.in (B.B.)
}

Citation: Kashyap, U.; Chandel, A.; Sharma, D.; Bhardwaj, S.; Bhargava, B. Propagation of Jasminum parkeri: A Critically Endangered Wild Ornamental Woody Shrub from Western Himalaya. Agronomy 2021, 11, 331. https://doi.org/10.3390/ agronomy11020331

Academic Editor: Anastasios Darras Received: 22 December 2020

Accepted: 1 February 2021

Published: 13 February 2021

Publisher's Note: MDPI stays neutral with regard to jurisdictional claims in published maps and institutional affiliations.

Copyright: (c) 2021 by the authors. Licensee MDPI, Basel, Switzerland. This article is an open access article distributed under the terms and conditions of the Creative Commons Attribution (CC BY) license (https:// creativecommons.org/licenses/by/ $4.0 /)$.

\begin{abstract}
Jasminum parkeri Dunn is a narrowly endemic, critically endangered woody ornamental shrub confined to sub-temperate zone of Western Himalayas, and rediscovered from its type locality after a lapse of about 100 years. In the present study, a propagation technique of J. parkeri, using stem cuttings, was established for the first time through application of auxins, namely, indole-3-acetic acid (IAA), 1-naphthaleneacetic acid (NAA), and indole-3-butyric acid (IBA), at varying concentrations ranging from 1000 to $4000 \mathrm{ppm}$. The highest rooting percentage $(98.33 \%(85.68 \% \pm 4.32))$, number of primary roots (36), root length $(29.68 \mathrm{~cm})$ and survival percentage $(96.67 \%(83.85 \% \pm 6.16))$ were recorded for cuttings treated with 3000 ppm NAA. The phenological comparison between pot plants propagated through seeds and stem cuttings in a naturally ventilated polyhouse revealed a reduction in vegetative and flowering phases in cutting raised plants. Additionally, a noteworthy adaptive behavior of two weeks of early flowering and four weeks of extended flowering (February to October) was observed in plants raised under polyhouse conditions. This method will help in protecting the species from population decline, thereby significantly increasing its potential to be harnessed as an ornamental plant in India. Furthermore, plants grown ex situ will be reintroduced in natural populations.
\end{abstract}

Keywords: woody ornamental; endemic; Jasminum parkeri; propagation; plant growth regulators

\section{Introduction}

The Indian Himalayan Region (IHR), known as one of the major biodiversity areas globally, accounts for around 50\% of the total number of angiosperms in India, of which 30\% are endemic [1,2]. The Western Himalaya is one of 25 micro-centers of endemic plants [3] that covers more than $50 \%$ area of the IHR. The biodiversity rich regions maintain ecological balance and offer bionetwork services for the welfare of people [2]. However, continued anthropogenic activities have led to unsustainable exploitation of natural resources, which has been exacerbated by the change in climate [2,4]. In turn, this has resulted in the extinction of a number of species, while a large proportion of the Himalayan biodiversity is facing the danger of extinction.

Jasminum parkeri Dunn, commonly known as dwarf jasmine, Himalayan jasmine, or Parkers jasmine, is one such endangered taxon, and is narrowly endemic and particularly found in the sub-temperate zone of the Western Himalaya [5]. It has bright yellow, pleasantly scented, and eye-catching flowers, and appears as a natural bonsai-like shrub. However, to date, its ornamental potential has not been explored in India, the nation of its origin. J. parkeri has not been cultivated for commercial purposes in its native country, although it can be popularized as a novel ornamental plant. It is found naturally in crevices of rocks along the slopes of grazing land and roadside edges at an altitude of 1600-2300 $\mathrm{m}$ a.s.1. The species was rediscovered by Lal et al. [5] from its type location after 
a lapse of 10 decades. Due to its narrow distribution, appropriate conservation measures are required, not only to guard this species from population decline, but also to benefit tribal people through its cultivation.

Ex situ conservation plays a significant role in protecting plant species, as an insurance policy for future periods, a basis for restoration and reintroduction programs, and for adaptation support of livelihoods against climate change [6]. Until now, no effort has been made for the multiplication of this species and, therefore, conservation policies such as clonal propagation and ex situ germplasm conservation should commence. J. parkeri can be propagated from seeds, but has a low germination percentage and slow seedling growth. Propagation by asexual means can be an effective alternative approach in sustaining genetic identity and populations [7]. Hence, propagation through cuttings should be considered. However, information is not available with reference to vegetative propagation of this species through stem cuttings. In cultivation of ornamental plants from cuttings, plant growth regulators (PGRs) play an essential role in growth regulation, propagation, and metabolic and physiological processes [8,9]. Previously, no research has been carried out on the use of PGRs in propagation of J. parkeri, thus the experiment was designed to identify the most favorable auxin (indole-3-acetic acid (IAA), 1-naphthaleneacetic acid (NAA), and indole-3-butyric acid (IBA)) treatment for successful propagation to conserve the species and harness its ornamental potential.

\section{Materials and Methods}

\subsection{Experimental Location}

The experiment was carried out in the greenhouse of the botanical garden at the CSIR-Institute of Himalayan Bioresource Technology, Palampur, Himachal Pradesh, India (latitude $32.1052^{\circ} \mathrm{N}$, longitude $76.5564^{\circ} \mathrm{E}$ ), located in the province of the Dhauladhar ranges at 1296 m a.s.l., from December 2018 to October 2020. Palampur experiences a humid subtropical climate with cool winters and hot summers. The optimum daily maximum and minimum temperatures of the greenhouse during the course of our study were recorded as 25.60 and $13.84{ }^{\circ} \mathrm{C}$, respectively. During summer months, evaporative cooling through a fan and pad system was used in the greenhouse to moderate the temperature conditions during the day. The system consisted of a $13.00 \mathrm{~cm}$ thick cellulose pad located on the air inlet at the south wall that was $9.00 \mathrm{~m}$ in width and $2.00 \mathrm{~m}$ in height, with the bottom edge $1.00 \mathrm{~m}$ above ground level, and used two exhaust fans $(413 \mathrm{~V}, 50 \mathrm{~Hz})$ at the other end of the greenhouse.

\subsection{Source of Plant Material}

Field grown healthy plants of J. parkeri (2.5-years-old) were procured from the botanical garden, CSIR-IHBT, and used as a source of seeds and cuttings. Seeds were collected in the month of January 2018 and sown in pots with a mixture of soil, sand, and farmyard manure in ratio of 1:1:1 at the greenhouse. Sub-apical semi-hardwood stem cuttings with $10-12$ nodes and 12-14 cm in length were collected in the month of February 2018 from the selected plants. The cuttings were immediately transported to the experimental sites in polythene bags to prevent desiccation.

\subsection{Rooting Growth Regulators Treatment}

The basal part of cuttings was saturated in $0.1 \%$ water solution of Bavistin (Crystal Crop Protection Pvt. Ltd., Delhi, India) for the duration of $15 \mathrm{~min}$ and cleaned by washing subsequently with double distilled water. The basal ends $(2-3 \mathrm{~cm}$ portion) of the cuttings were then treated with the auxins, i.e., indole-3-butyric acid (IBA), indole-3-acetic acid (IAA), and 1-naphthalene acetic acid (NAA), in concentrations ranging from 1000 to $4000 \mathrm{ppm}$ for $1 \mathrm{~h}$. The treated cuttings were planted in plastic pots $(22.5 \mathrm{~cm}$ diameter, $18.0 \mathrm{~cm}$ height) filled with rooting medium of sterilized pre-soaked sand. The double distilled water treated cuttings were used as the control. Auxins were bought from HIMEDIA, Himedia Laboratories Pvt. Ltd., Mumbai, Maharashtra, India, and an aqueous solution 
was prepared by dissolving in $40 \mathrm{~mL}$ of $99.9 \%$ ethyl alcohol (Changshu Hongsheng Fine Chemicals Co., Ltd., ChangShu, China) followed by dilution with $1 \mathrm{~L}$ distilled water, and applied on the same day of preparation for the experiment.

\subsection{Morphological Assessment}

The data on morphological characteristics (sixty plants per treatment), such as root length $(\mathrm{cm})$, rooting percentage, and number of roots, were recorded 24 weeks after planting of cuttings. The rooted cuttings were then transplanted in plastic pots $(22.5 \mathrm{~cm}$ diameter, $18.0 \mathrm{~cm}$ height) containing a mixture of farmyard manure, soil, and sand in a 1:1:1 ratio. The survival percentage, leaf number, number of shoots, and stem diameter $(\mathrm{mm})$ were recorded after the cuttings were hardened and acclimatized for 8 weeks.

\subsection{Vegetative and Flowering Phenology}

The vegetative and flowering phenological phases of J. parkeri (thirty plants per treatment) pot plants were observed at weekly intervals for a period of 2 years (Figures 1 and 2). The day at which the first flower opened and the number of plants that flowered, based on visual estimates, were recorded.

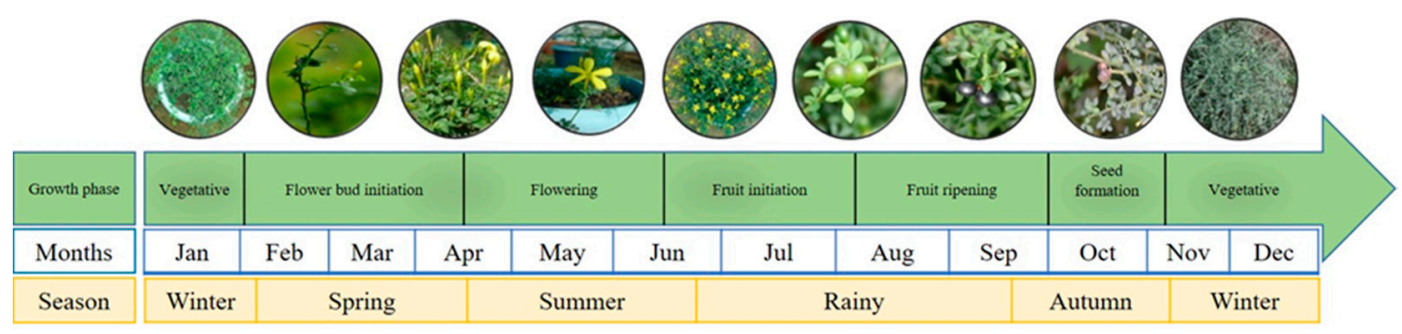

Figure 1. Phenological stages of Jasminum parkeri in a naturally ventilated polyhouse.
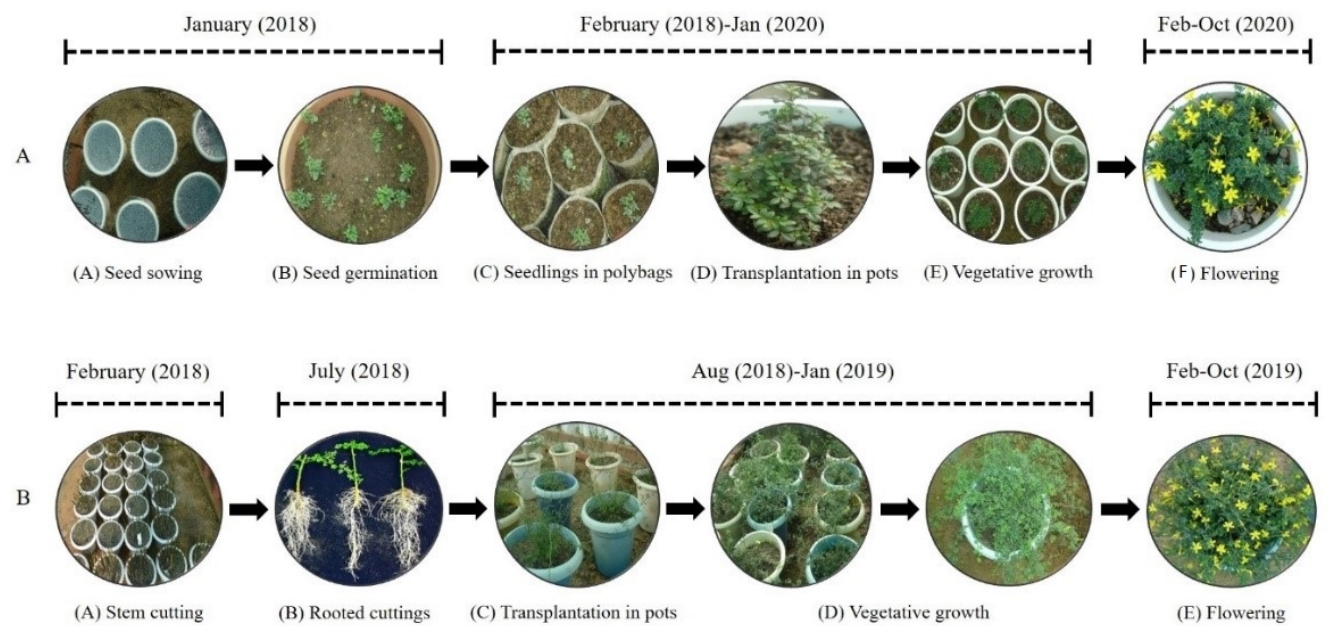

Figure 2. Vegetative and flowering stages during propagation of Jasminum parkeri: (A)—through seed; (B)—through stem cuttings.

\subsection{Data Analysis}

All of the results of experiment are expressed as mean \pm standard error (SE) using the statistical software SPSS 25.0.0 (Statistical Program for Social Sciences Corporation, Chicago, USA). One-way analysis of variance (ANOVA) with Duncan's multiple range tests (DMRT) were implemented for the comparison of mean values $(p \leq 0.05)$, where the letters designated in the graphs show the difference between the means. In this experiment, 780 cuttings were used in 12 different treatments; every treatment consisted of a total of 60 cuttings having three replications, each replication consisting of 20 cuttings. 


\section{Results}

\subsection{Rooting Response of Stem Cuttings}

The stem cuttings treated with exogenous auxins (IBA, IAA, and NAA) at varying concentrations (1000 to $4000 \mathrm{ppm}$ ) (Figures 3 and 4), revealed that a better rooting percentage $(98.33 \%(85.68 \% \pm 4.32))$ was observed in cuttings treated with NAA (3000 ppm) compared to the control $(85.00 \%(67.96 \% \pm 4.55))$ and treatment with IBA and NAA at $1000 \mathrm{ppm}$ (Figure 3A). Greater root length $(29.68 \mathrm{~cm})$ was induced in cuttings treated with NAA at $3000 \mathrm{ppm}$ (Figure 3B), which was statistically at par with treatments of IBA (3000 ppm, $27.88 \mathrm{~cm})$, IAA ( $3000 \mathrm{ppm}, 27.13 \mathrm{~cm})$, and IAA $(4000 \mathrm{ppm}, 26.33 \mathrm{~cm})$. The largest number of primary roots (36.00) was recorded in cuttings treated with NAA at $3000 \mathrm{ppm}$ (Figure 3C) compared to the number of roots in the control and all treatments with PGRs. The auxin treatments significantly affected the survival percentage in cuttings. The semi-hardwood cuttings treated with $3000 \mathrm{ppm}$ NAA were recorded with the highest survival percentage $(96.67 \%(83.85 \% \pm 6.16))$, which was significantly at par with treatments IBA (3000 ppm, $91.67 \%(76.24 \% \pm 6.99))$, NAA (2000 ppm, 93.33\% (75.21\% \pm 1.84$))$, and IAA (4000 ppm, $91.67 \%(73.76 \% \pm 3.29))$. The lowest survival percentage $(63.33 \%(52.72 \% \pm 0.99))$ was found for cuttings in the control (Figure 3D).
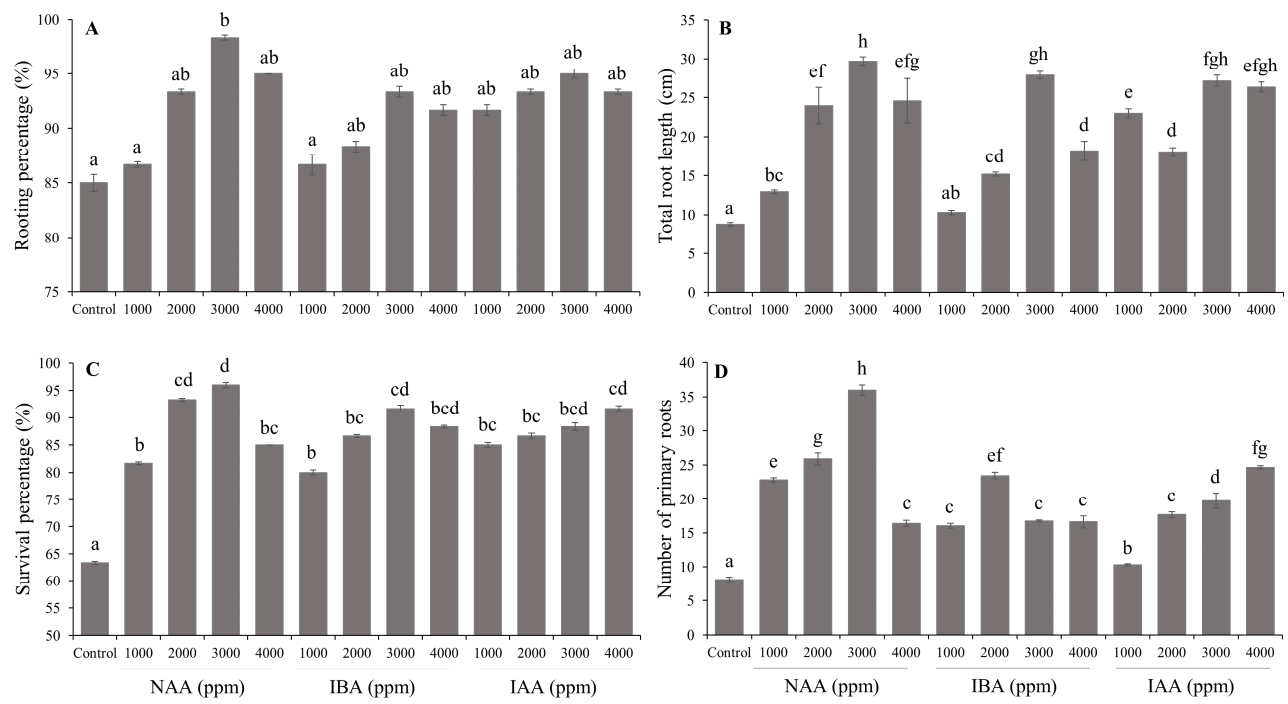

Figure 3. Effect of auxin treatment: (A) rooting percentage; (B) total root length; (C) number of primary roots; (D) survival percentage of Jasminum parkeri stem cuttings. Different letters indicate significant mean difference among treatments (DMRT, $p \leq 0.05)$
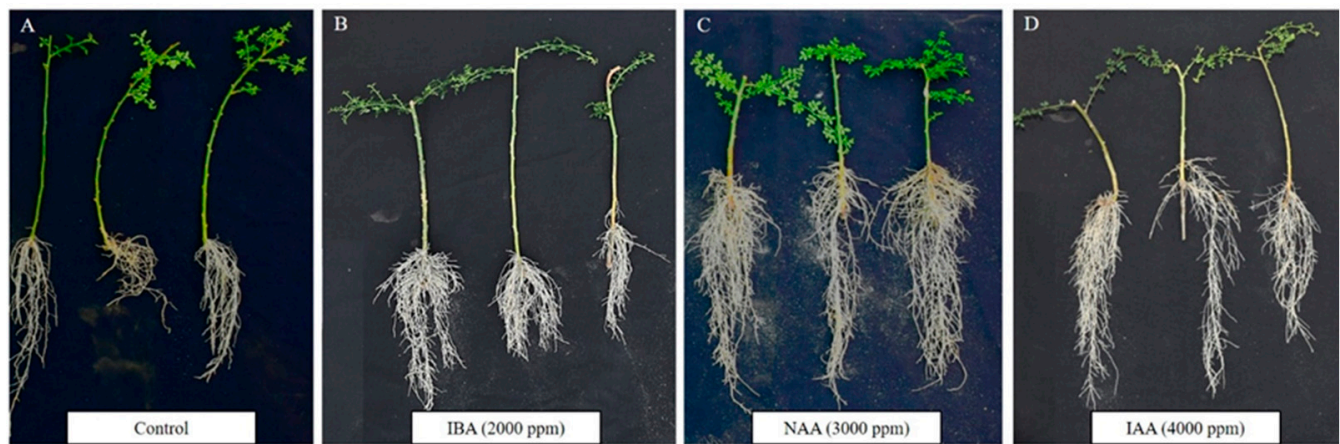

Figure 4. Root formation in Jasminum parkeri cuttings as affected by different auxin treatments. 


\subsection{Shoot Formation in Rooted Cuttings}

The data on shoot formation in rooted cuttings, after 8 weeks of transplanting, is represented in Figure 5. The higher number of leaves (33.93) were recorded in cuttings treated with IAA (2000 ppm) and IBA (2000 ppm) compared to the control (25.87) (Figure 5A). For all of the treatments, the number of shoots was over 2.60 (Figure 5B), whereas, the average stem diameter was $2.88 \mathrm{~mm}$ (Figure 5C).

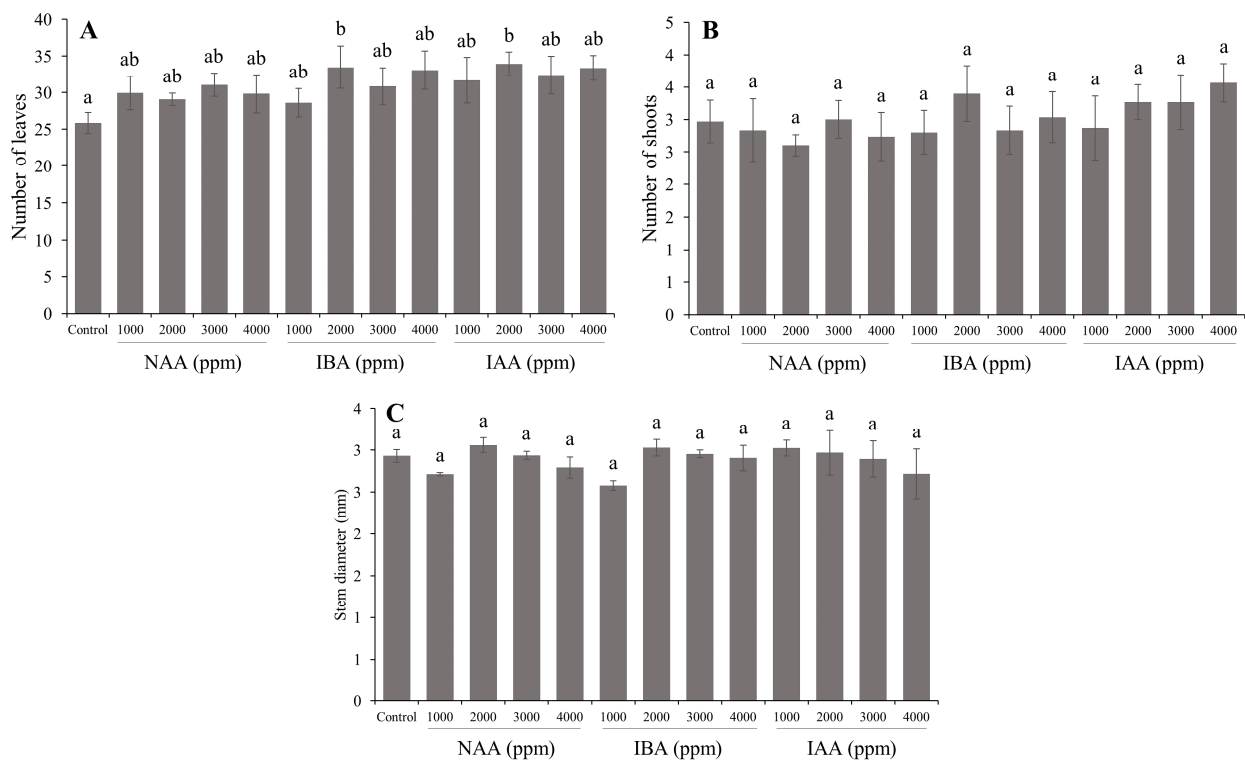

Figure 5. Effect of auxin treatment: (A) number of leaves; (B) number of shoots; (C) stem diameter of Jasminum parkeri stem cuttings. Different letters indicate significant mean difference among treatments (DMRT, $p \leq 0.05$ ).

\subsection{Vegetative and Flowering Phenology}

The phenology of J. parkeri plants propagated through seeds and stem cuttings in naturally ventilated polyhouse conditions were observed. A comparison between duration of vegetative and flowering phase of plants raised in the polyhouse through seeds and cuttings was made (Figure 6). The visual estimates revealed that the pot plants propagated through seed remained in the vegetative phase for almost 2 years (January 2018 to January 2020) and took more than two years to reach the flowering stage, whereas the vegetative cycle duration in J. parkeri cuttings was reduced to half (around 1 year, February 2018 to January 2019) and the flowering stage was reached after a year of planting (Figure 2A). The plants raised through stem cuttings produced visible buds at the 26th week (January, 2019), flowering was initiated within a week (up to the 65th week; February 2019 to October 2019) (Figure 6), and peak flowering was observed for 6 weeks (38th week to 43rd week; April 2019 to May 2019). By comparison, the seed-raised plant produced visible buds at the 28th week of the second year (February 2020), the flowering was initiated after a week (up to the 61st week; February 2020 to September 2020) (Figures 2A and 6), and the peak flowering was observed for three weeks (43rd week to 45th week; April 2020 to May 2020). Fruit initiation, fruit ripening, and seed setting started in plants raised through cuttings from the 45th, 54th, and 63rd weeks (June 2019 to October 2019), whereas in plants raised through seeds, the process of fruit initiation, fruit ripening, and seed setting started from the 48th, 56th, and 65th weeks (June 2020 to November 2020). 


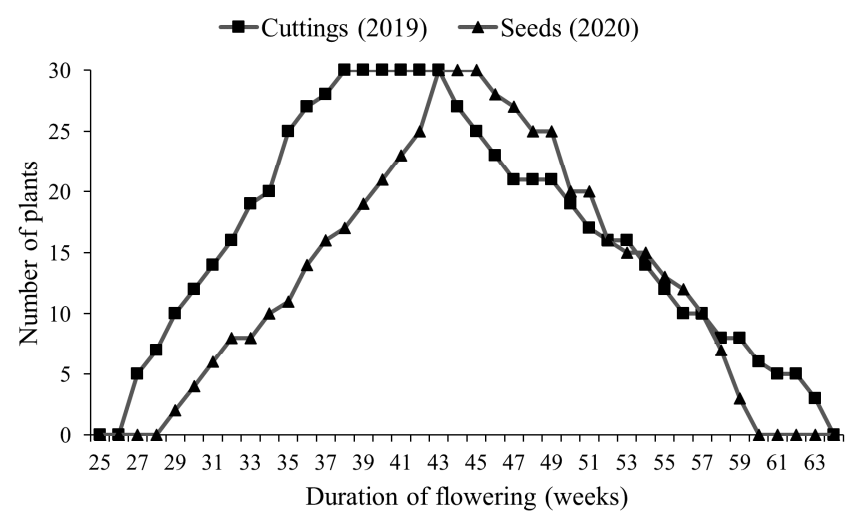

Figure 6. Line graph representing the variation (at weekly intervals) in the duration of flowering with the number of Jasminum parkeri plants $(n=30)$ propagated through stem cuttings and seeds.

\section{Discussion}

Asexual propagation through stem cuttings is a useful tool in conservation of endangered and threatened plant species with insufficient natural revival and poor seed germination [10]. In the present investigation, the sub-apical semi-hardwood stem cuttings of $J$. parkeri showed good potential for root induction, but varied with auxin concentrations (1000 to $4000 \mathrm{ppm}$ ). Auxin is commonly applied in the vegetative propagation of plants because it can stimulate adventitious rooting in cuttings; increase the overall rooting percentage, root number, and quality of roots; and encourage rooting uniformity [11-13]. The stem cuttings were most responsive to NAA at $3000 \mathrm{ppm}$ concentration for rooting percentage, total root length, and number of primary roots. Kishore [14] reported maximum rooting percentage $(73.33 \%)$, percent survival $(73.33 \%)$, and number of roots (17.00) in Jasminum humile semi-hardwood cuttings treated with NAA (4500 ppm). Singh [15] also observed maximum rooting $(100 \%)$ in cuttings of $J$. sambac cv. Madhanban treated with NAA (4000 ppm). In other species, such as Tecoma stans, semi-hardwood cuttings exhibited maximum rooting percentage $(80.90 \%)$ and root length $(16.75 \mathrm{~cm})$ with 3000 ppm NAA [16]. The meagre performance of IBA and IAA for root induction, in comparison to NAA, could be because of its light sensitivity and enzyme IAA oxidase, which destroys IAA and does not affect NAA [10,17,18], increased ethylene (a root inhibitor) level [19], and variance in the level of reserve food materials [20], such as polysaccharides and nutrients, which hydrolyze and mobilize to the cutting base under the influence of NAA [21]. Untreated stem cuttings (control) were also able to root, but with a low rooting percentage in comparison to auxintreated cuttings, possibly due to the presence of stored carbohydrates and endogenous auxin contents in the cuttings at the time of severance [22]. Similar findings were reported by Pandey et al. [23] in Ginkgo biloba L. cuttings treated with IBA. The increase in auxin concentration positively influenced shoot formation in J. parkeri cuttings and treatment with IAA at $2000 \mathrm{ppm}$ resulted in the production of the maximum number of leaves and greatest shoot length. According to Stancato et al. [24], the escalation in leaf number could be due to the presence of a vigorous rooting system induced by auxin treatment, enabling the cuttings to absorb additional nutrients, thus resulting in the production of more leaves. Reddy et al. [25] reported maximum cumulated shoot length $(5.73 \mathrm{~cm})$ in Pelargonium graveolens cuttings treated with IAA at $2000 \mathrm{ppm}$ concentration. This can be attributed to cell elongation, which results in increased linear growth of the stem [26]. The survival rate of sub-apical stem cuttings of J. parkeri, after 8 weeks of hardening and acclimatization, was higher under polyhouse conditions due to improved establishment and anchorage of rooted cuttings because of auxin treatment [27]. In the present study, a reduction in the rooting response and stem formation was observed at concentration above $3000 \mathrm{ppm}$, indicating the possibility of damaging effects of auxin at high concentrations; damage included intensified green leaf pigmentation, stem curvature, and growth inhibition. The biosynthesis of ethylene stimulated at high auxin concentrations triggers abscisic acid 
(ABA) production, resulting in stomatal closure in addition to promotion of leaf senescence and, ultimately, death [28].

The phenological studies of the present investigation conveyed for the first time that the duration of the vegetative and the flowering cycles was reduced to half in plants raised from cuttings of J. parkeri compared to those raised through seeds. Two weeks of early flowering and four weeks of extended flowering was also observed in plants raised from stem cuttings compared to plants raised through seeds. The peak flowering was recorded early (for 6 weeks) for plants raised through stem cuttings. Consistent with our study, Lal et al. [5] reported that May-December is the flowering and fruiting period of J. parkeri plants growing in their natural habitat.

\section{Conclusions}

Overall, the present findings highlighted that the exogenous application of NAA (3000 ppm), IAA (4000 ppm), and IBA (3000 ppm) resulted in successful propagation of J. parkeri. Furthermore, it can be concluded that auxin application has decisive effects on the survival and development of J. parkeri cuttings. This method offers a reproducible, simple, feasible, and economical method for large-scale multiplication of J. parkeri plants for reinforcement of existing wild populations, thereby significantly increasing its potential to be harnessed as an ornamental plant in India.

Author Contributions: U.K. and B.B., Conceived the concept, U.K., A.C. and B.B., Framed the experimental design, U.K., D.S. and S.B., Data taken and statistical analysis, U.K. and B.B., Manuscript written and edition. All authors have read and agreed to the published version of the manuscript.

Funding: The authors acknowledge the financial assistance provided by Ministry of Environment, Forest and Climate Change (MoEF \& CC), Government of India, under the project "Ex-situ conservation of rare, endangered, threatened, endemic \& economic plant resources of western Himalayan region through botanical garden" (GAP-210).

Institutional Review Board Statement: Not applicable.

Informed Consent Statement: Not applicable.

Data Availability Statement: All data generated or analyzed during this study are included in this published article [and its supplementary information files]. Further, the datasets used and/or analyzed during the current study are available from the corresponding author on reasonable request.

Acknowledgments: The authors are thankful to the Director, Sanjay Kumar, CSIR-IHBT for providing necessary facilities. The authors are also grateful to Brij Lal, Retd. Chief Scientist, CSIR-IHBT for introducing J. parkeri plants to the botanical garden of the institute.

Conflicts of Interest: All authors declare no conflict of interest.

\section{References}

1. Pimm, S.L.; Jenkins, C.N.; Abell, R.; Brooks, T.M.; Gittleman, J.L.; Joppa, L.N.; Raven, P.H.; Roberts, C.M.; Sexton, J.O. The biodiversity of species and their rates of extinction, distribution, and protection. Science 2014, 344, 1246752. [CrossRef] [PubMed]

2. Mehta, P.; Chandra Sekar, K.; Bhatt, D.; Tewari, A.; Bisht, K.; Upadhyay, S.; Negi, V.S.; Soragi, B. Conservation and prioritization of threatened plants in Indian Himalayan Region. Biodivers. Conserv. 2020, 29, 1723-1745. [CrossRef]

3. Venkataraman, K.; Sivaperuman, C. Biodiversity hotspots in India. In Indian Hotspots; Springer: Singapore, 2018 ; pp. 1-27.

4. Rands, M.R.; Adams, W.M.; Bennun, L.; Butchart, S.H.; Clements, A.; Coomes, D.; Entwistle, A.; Hodge, I.; Kapos, V.; Scharlemann, J.P.; et al. Biodiversity Conservation: Challenges Beyond 2010. Science 2010, 329, 1298-1303. [CrossRef]

5. Lal, B.; Datta, A.; Parkash, O.; Singh, R.D. Rediscovery of Jasminum parkeri Dunn, an endemic and endangered taxon from the western Himalaya, India. Biodivers. Res. Conserv. 2014, 34, 11-16. [CrossRef]

6. Seaton, P.T.; Hu, H.; Perner, H.; Pritchard, H.W. Ex Situ Conservation of Orchids in a Warming World. Bot. Rev. 2010, 76, 193-203. [CrossRef]

7. Deepak, K.G.K.; Suneetha, G.; Surekha, C. A simple and effective method for vegetative propagation of an endangered medicinal plant Salacia oblonga Wall. J. Nat. Med. 2016, 70, 115-119. [CrossRef] [PubMed]

8. Sajjad, Y.; Jaskani, M.J.; Asif, M.; Qasim, M. Application of plant growth regulators in ornamental plants: A review. Pak. J. Agric. Sci. 2017, 54, 327-333. 
9. Salachna, P.; Zawadzińska, A. Effect of daminozide and flurprimidol on growth, flowering and bulb yield of Eucomis autumnalis (Mill.) Chitt. Folia Hortic. 2017, 29, 33-38. [CrossRef]

10. Hartmann, H.T.; Kester, D.E.; Davies, F.T.; Geneve, R.L. Hartmann and Kester's Plant Propagation: Principles and Practices; PrenticeHall: Upper Saddle River, NJ, USA, 2010.

11. Blythe, E.K.; Sibley, J.L.; Tilt, K.M.; Ruter, J.M. Methods of auxin application in cutting propagation: A review of 70 years of scientific discovery and commercial practice. J. Environ. Hortic. 2007, 25, 166-185. [CrossRef]

12. Da Costa, C.T.; De Almeida, M.R.; Ruedell, C.M.; Schwambach, J.; Maraschin, F.D.S.; Fett-Neto, A.G. When stress and development go hand in hand: Main hormonal controls of adventitious rooting in cuttings. Front. Plant Sci. 2013, 4, 133. [CrossRef]

13. Lakehal, A.; Chaabouni, S.; Cavel, E.; Le Hir, R.; Ranjan, A.; Raneshan, Z.; Novák, O.; Păcurar, D.I.; Perrone, I.; Jobert, F.; et al. A Molecular Framework for the Control of Adventitious Rooting by TIR1/AFB2-Aux/IAA-Dependent Auxin Signaling in Arabidopsis. Mol. Plant 2019, 12, 1499-1514. [CrossRef]

14. Kishore, G.R. Effect of type of cuttings and concentration of NAA on the rooting performance of jasmine (Jasminum humile). Hortflora Res. Spectr. 2016, 5, 86-87.

15. Singh, S.P. Rooting studies in Jasminum sambac cw 'Madanban' by terminal cuttings under intermittent mist with the aid of auxins. South Indian Hortic. 1979, 27, 68-69.

16. Ashok, A.D.; Ravivarman, J. Efficacy of naphthalene acetic acid on root promotion on vegetative propagation of Tecoma stans under mist chamber of semi-arid tropic region. J. Pharmacogn. Phytochem. 2020, 9, 3000-3002.

17. Nissen, S.J.; Sutter, E.G. Stability of IAA and IBA in nutrient medium to several tissue culture procedures. HortScience 1990, 25, 800-802. [CrossRef]

18. Prajapati, N.; Padhiar, B.V.; Patel, P.U.; PATEL, P. Effect of Plant Growth Regulators on Rooting of Cutting in Black Pepper (Piper nigrum L.) cv. Panniyar-1 Under Protected Condition. Trends Biosci. 2018, 11, 2133-2136.

19. Negi, S.; Ivanchenko, M.G.; Muday, G.K. Ethylene regulates lateral root formation and auxin transport in Arabidopsis thaliana. Plant J. 2008, 55, 175-187. [CrossRef]

20. Bhardwaj, D.R.; Mishra, V.K. Vegetative propagation of Ulmus villosa: Effects of plant growth regulators, collection time, type of donor and position of shoot on adventitious root formation in stem cuttings. New For. 2005, 29, 105-116. [CrossRef]

21. Shao, F.; Wang, S.; Huang, W.; Liu, Z. Effects of IBA on the rooting of branch cuttings of Chinese jujube (Zizyphus jujube Mill.) and changes to nutrients and endogenous hormones. J. For. Res. 2018, 29, 1557-1567. [CrossRef]

22. Dick, J.M.; Leakey, R.R.B. Differentiation of the dynamic variables affecting rooting ability in juvenile and mature cuttings of cherry (Prunus avium). J. Hortic. Sci. Biotechnol. 2006, 81, 296-302. [CrossRef]

23. Pandey, A.; Tamta, S.; Giri, D. Role of auxin on adventitious root formation and subsequent growth of cutting raised plantlets of Ginkgo biloba L. Int. J. Biodivers. Conserv. 2011, 3, 142-146.

24. Stancato, G.C.; Aguiar, F.F.A.; Kanashiro, S.; Tavares, A.R.; Catharino, E.L.M.; Silveira, R.B.D.A. Rhipsalis grandiflora Haw.(Cactaceae) propagation by stem cuttings. Sci. Agric. 2003, 60, 651-656. [CrossRef]

25. Reddy, C.P.; Chandrasekhar, R.; Reddy, Y.N.; Rajkumar, M. Effect of growth regulators on rooting of Scented geranium (Pelargonium graveolens L.) cuttings. J. Res. Angru 2005, 33, 114-116.

26. Seran, T.H.; Umadevi, T. Influence of Indole Acetic Acid (IAA) on the establishment of stem cuttings in lemon (Citruslimon, L.). J. Agric. Res. 2011, 49, 517-524.

27. Opuni-Frimpong, E.; Karnosky, D.F.; Storer, A.J.; Cobbinah, J.R. Key Role of Leaves, Stock Plant Age, and Auxin Concentration in Vegetative Propagation of Two African Mahoganies: Khaya anthotheca Welw. and Khaya ivorensis A. Chev. New For. 2008, 36, 115-123. [CrossRef]

28. Grossmann, K. Mode of action of auxin herbicides: A new ending to a long, drawn out story. Trends Plant Sci. 2000, 5, 506-508. [CrossRef] 